\title{
The origins of paraffinic oils collected from oilfields in the western Siberian Basin, Russia: implications from geochemical and physical characteristics
}

\author{
Mohammed Hail Hakimi ${ }^{1,2}$. Shadi A. Saeed ${ }^{2}$. Ameen A. Al-Muntaser ${ }^{2}$ - Mikhail A. Varfolomeev ${ }^{2,3}$. \\ Richard Djimasbe ${ }^{2} \cdot$ Aref Lashin $^{4} \cdot$ Nura Abdulmumini Yelwa ${ }^{5} \cdot$ Muneer A. Suwaid ${ }^{2,3}$
}

Received: 20 July 2021 / Accepted: 7 October 2021 / Published online: 19 October 2021

(c) The Author(s) 2021

\begin{abstract}
Four oil samples were collected from oilfields in the western Siberian Basin, and analyzed using conventional geochemical and physical methods. The results of this study were used to evaluate the oil samples, focusing on the characteristics of their source rocks, including the origin of organic matter input; redox depositional conditions and degree of thermal maturity of their probable source rock were studied. The obtained SARA results show that the examined oils are paraffinic oils owing to their high saturated hydrocarbon fraction values of greater than $70 \%$ volume. The observed API gravity values $\left(23.55^{\circ}\right.$ to $32.57^{\circ}$ ) and low sulfur content of less than $0.25 \% \mathrm{wt}$ indicate that the examined oils are sweet oils and were generated from source rock containing Type-II, with low sulfur content. The low sulfur content combined with the vanadium (V) and nickel $(\mathrm{Ni})$ ratios indicates that the examined oils were scoured from a mixture of aquatic and terrestrial organic matter, depositing under generally suboxic environmental conditions. The $n$-alkane and isoprenoid distributions, with their ratios and parameters further suggest that the examined oil samples were generated from source rock containing a mixed organic matter input and deposited under suboxic to relatively oxic environmental conditions. Bulk compositions and distributions of $n$-alkane and isoprenoid indicate that the oil samples were generated from mature source rock.
\end{abstract}

Keywords Paraffinic oil $\cdot$ Sulfur-low content $\cdot$ Bulk property $\cdot$ Mature oil $\cdot$ Western Siberian Basin, Russia

\section{Introduction}

The study area, the western Siberian Basin (Fig. 1), is a promising area for hydrocarbon (HC) exploration in the world (Fig. 1), with mainly oil and gas fields being exported

Mohammed Hail Hakimi

ibnalhakimi@yahoo.com

$\triangle$ Mikhail A. Varfolomeev

Mikhail.Varfolomeev@kpfu.ru

1 Geology Department, Faculty of Applied Science, Taiz University, 6803 Taiz, Yemen

2 Department of Petroleum Engineering, Kazan Federal University, Kazan, Russia 420008

3 Department of Physical Chemistry, Kazan Federal University, Kazan, Russia 420008

4 College of Engineering-Petroleum and Natural Gas Engineering Department, King Saud University, Riyadh 11421, Saudi Arabia

5 Department of Geology, Usmanu Danfodiyo University, P.M.B. 2346, Sokoto, Nigeria
(U.S. Geological Survey World Energy Assessment Team 2000).

The western Siberian Basin is composed of Mesozoic sedimentary rocks, important conventional petroleum source and reservoir rocks, belonging to the Lower-Middle Jurassic Tyumen and Late Jurassic Bazhenov formations as source rocks and sandstone succession of Lower-Middle Jurassic Tyumen and Late Cretaceous Tanopcha and Pokur formations as reservoir rocks(Pyatkov et al. 1988; Kontorovich et al. 1991,1997; Belkin and Bachurin 1991; Peters et al. 1993; Afanasyev et al. 1993; Petrov 1994; Lopatin et al. 1997).

The most effective source rocks in the western Siberian Basin are mainly clay-rich rocks within the Lower-Middle Jurassic Tyumen and Late Jurassic Bazhenov formations 


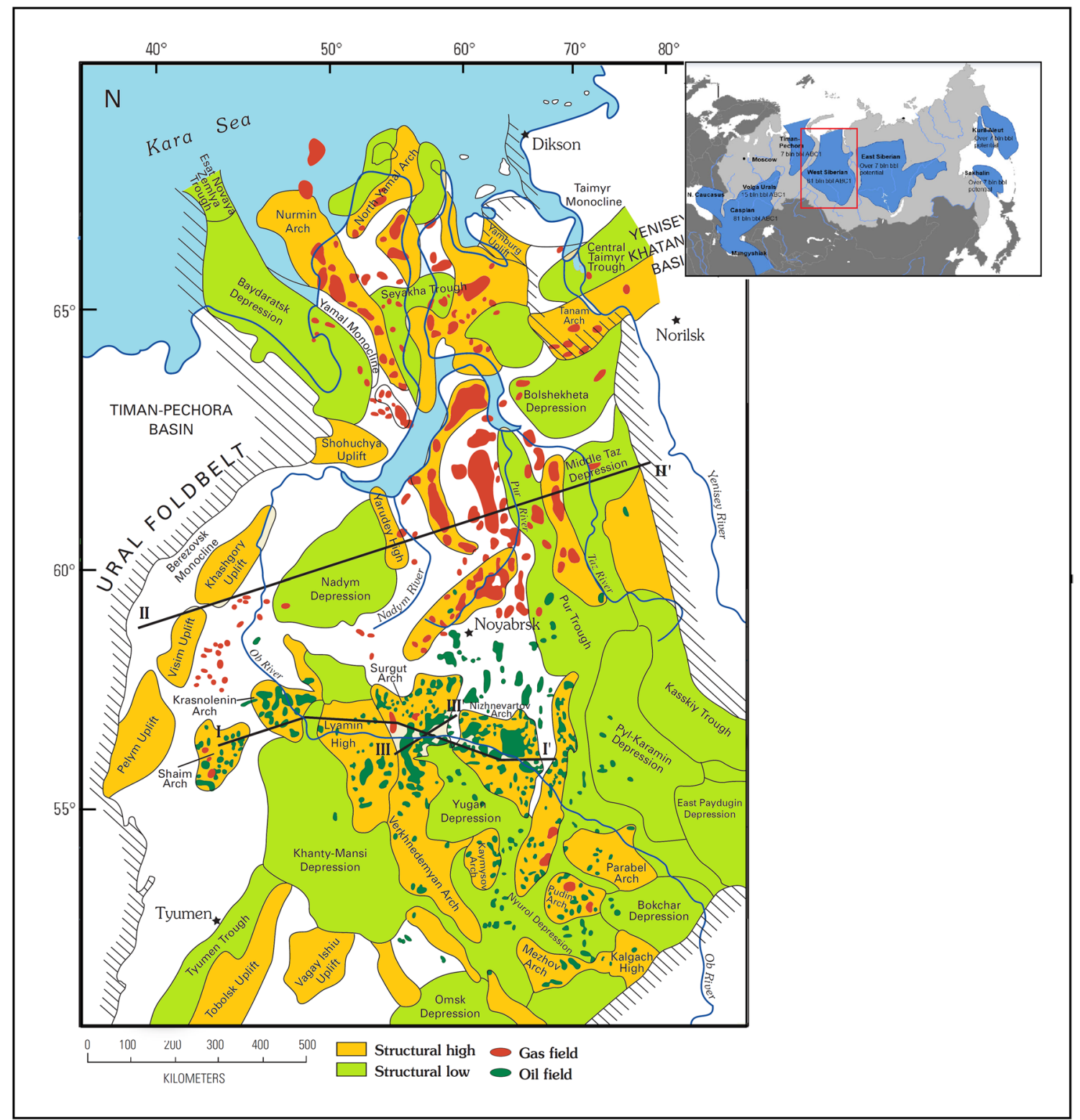

Fig. 1 Structural map of West Siberian basin, including oil and gas fields in the basin

(Fig. 2). The source rock potentials of these clay-rich rocks and their ability to generate petroleum in different parts of the western Siberian Basin have been investigated and reported previously (Lopatin et al. 1997, 1998; Kontorovich et al. 1997).

These studies indicate that the Jurassic clay-rich rocks within the Lower-Middle Jurassic Tyumen and Late Jurassic Bazhenov formations contain mainly Type II and mixed Type II/III kerogen; thus, they are likely to be high oil-source rocks (Lopatin et al. 1997, 1998; Kontorovich et al. 1997). However, little attention has been paid to the produced oils and the characteristics of their source rocks, such as organic matter input, depositional environmental conditions, and degree of thermal maturity.

In this study, we investigated the characteristics of the four oils from oilfields in the western Siberian Basin (Fig. 1) to obtain more information on the oil composition. Their kerogen types and level of their maturation, the origin of organic matter input, and depositional conditions of their probable source rocks are also investigated. 


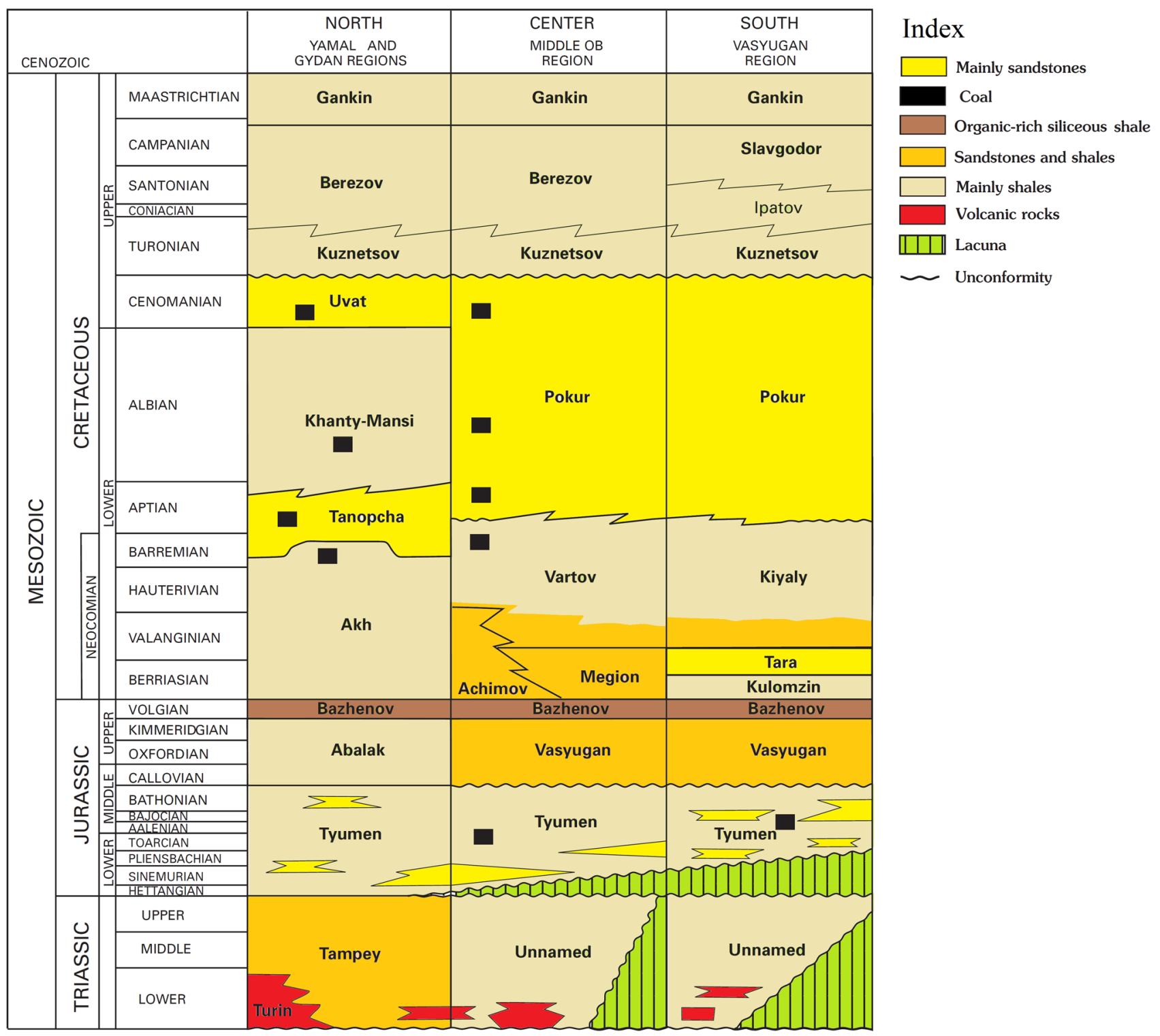

Fig. 2 Generalized stratigraphic column of the Mesozoic succession in the West Siberian basin

\section{Stratigraphic setting}

Geologically, the West Siberian basin is filled by Mesozoic sedimentary succession, ranging from Triassic to Cretaceous and related to the Early Triassic rift system (Surkov et al. 1997).

The Mesozoic sedimentary succession is dominated by clastic sediments punctuated by unconformities of various magnitudes and ages (Fig. 2). The Triassic package includes sediments of the Tampey Formation and is mainly composed of continental clastic rocks that unconformably overlie the Lower Triassic volcanic rocks (Fig. 2). The upper part of the Tampey Formation is overlain conformably by the Tyumen Formation in the northern basin and with unconformably contact in the central and south the basin (Fig. 2). The Lower-middle Jurassic Tampey Formation and its stratigraphic equivalents consist largely of continental coalbearing clastic rocks in the southern basin areas (Fig. 2). Northward, these continental rocks pass to paralic facies composed of interbedded continental and near shore marine clastic beds. The Marine facies in this formation become more abundant northward and upward in the section (Fig. 2).

The Tampey Formation is conformably overlain by deep marine shale sequence of the Callovian-Kimmeridgian Abalak Formation (Fig. 2). In the central and southern parts of the basin, the Callovian-Kimmeridgian section consists of alternating sandstones and shales of the Vasyugan Formation (Fig. 2). In Volgian- Early Berriasian 
(latest Jurassic-earliest Cretaceous) time, a deep-water anoxic depression formed in the entire central part of the West Siberian basin, including black, organic-rich, siliceous shales of the Bazhenov Formation (e.g., Vyshemirsky 1986; Rudkevich et al. 1988). The Bazhenov Formation is conformably overlain by mixed sandstone and shale sequence of the Early to Middle Cretaceous, including many formations such as Akh, Achimov, Megion, Tara, Kulomzin, Kiyalym, Vartov, Tanopcha, Khanty-Mansi and Pokur (Fig. 2). The Late Cretaceous shale deposits succeed the mixed sandstone and shale sequence of the Early to Middle Cretaceous with conformable contact (Fig. 1C).

\section{Sampling and analytical methods}

Four oil samples were collected from oilfields in the western Siberian Basin, Russia (Fig. 1 and Table 1). The oil samples were analyzed using multiple geochemical and physical approaches, including specific gravity (SG), sulfur (S) content, measurements of vanadium $(\mathrm{V})$ and nickel $(\mathrm{Ni})$ trace elements, fractionation of oil (SARA) and gas chromatography (GC) analysis of the saturated $\mathrm{HC}$ fraction. These analyses were conducted at the Departments of Petroleum Engineering and Physical Chemistry, Kazan Federal University and the results are made available in this study.

For specific gravity (SG) analysis, the oils samples were analyzed using a Stabinger Viscometer (SVM-3000). This machine allows a quick and accurate measurement of the dynamic and kinematic viscosity, density and other parameters of liquid media. The temperature range of Stabinger Viscometer (SVM-3000) varies from $15{ }^{\circ} \mathrm{C}$ to $105{ }^{\circ} \mathrm{C}$, examining highly viscous materials such as heavy oils and bitumen. Subsequently, the American Petroleum Institute (API) gravity was calculated according to the equation: API $=(141.5 / \mathrm{SG})-131.5$.

The oil samples were also subjected to ultimate analysis according to ASTM (P/N 0240-1289) guidelines. The whole oil samples were analyzed using a PE 2400 Series II CHNS/O Analyzer instrument. The sulphur (S), carbon (C), hydrogen $(\mathrm{H})$ and nitrogen $(\mathrm{N})$ were measured at $1100{ }^{\circ} \mathrm{C}$ as a burning temperature in the presence of oxygen as combustion gas.

The vanadium $(\mathrm{V})$ and nickel $(\mathrm{Ni})$ elements were also measured using a Clever $\mathrm{C}_{31}$ energy-dispersive $\mathrm{X}$-ray fluorescence spectrometer.

For SARA analysis, the asphaltene fraction from the SARA composition in the examined oils was precipitated by addition hexane (1:40). The others components (saturate, aromatic and resin) were determined by the liquid column chromatography separation using different solvents (Fig. 3). The saturated fraction was subsequently analyzed by applying on the Agilent 7890B with a flame ionization detector.

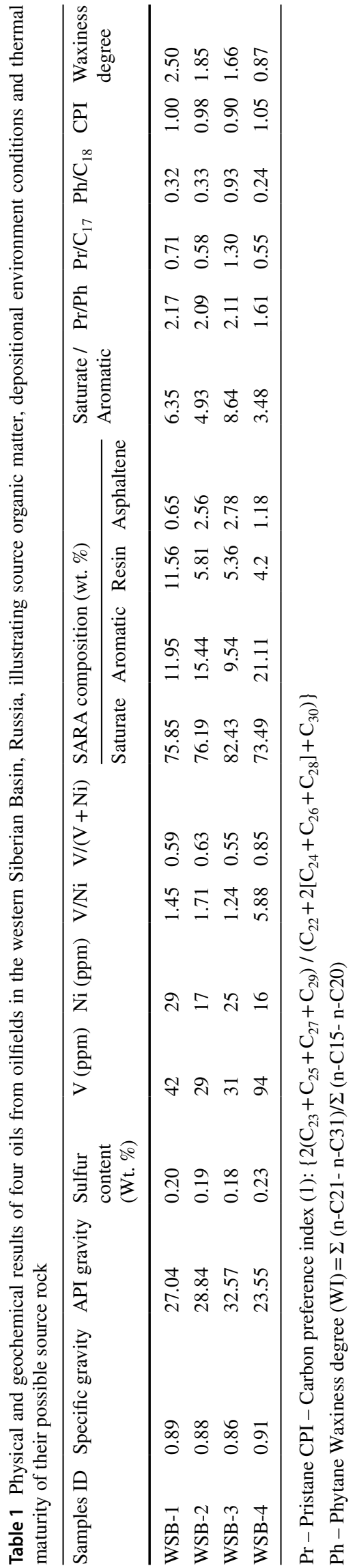



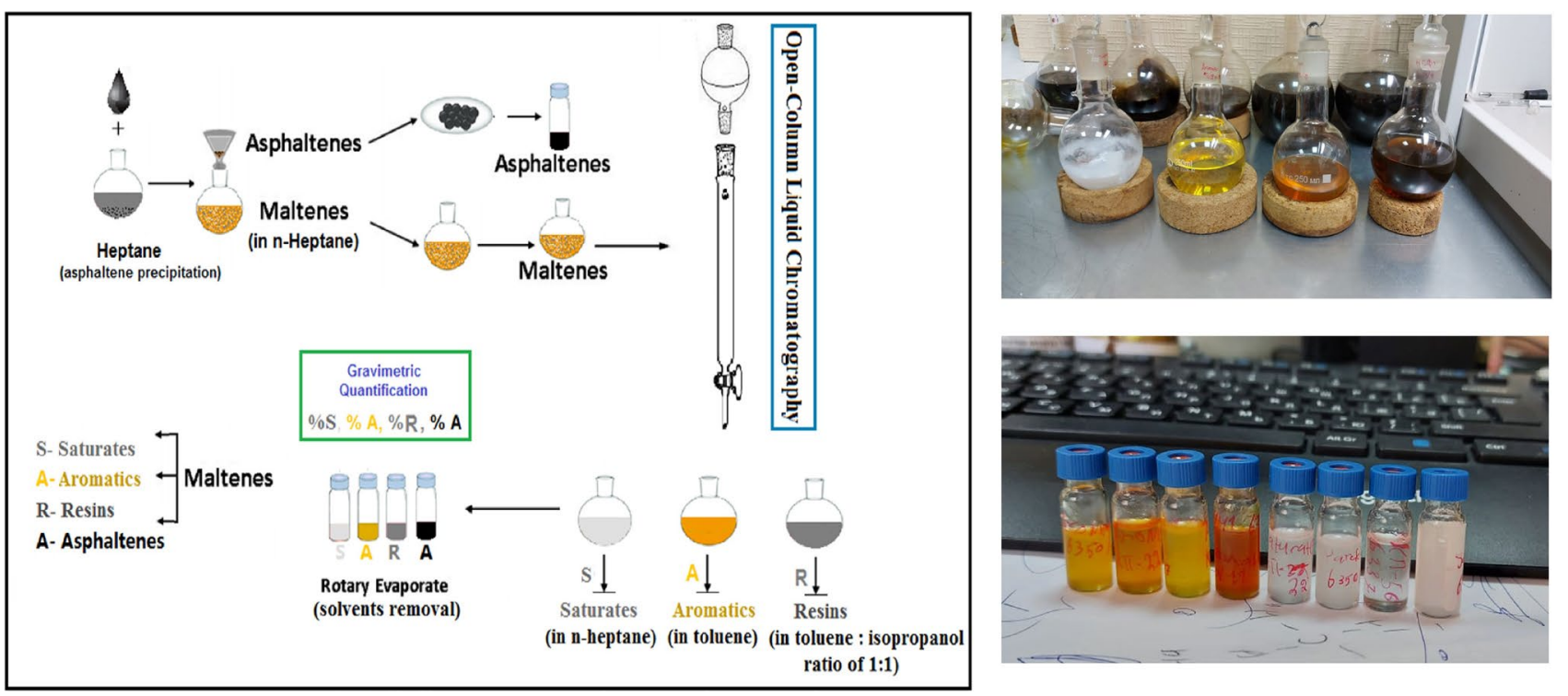

Fig. 3 The illustration scheme of the SARA separation process ( modified from Al-Muntaser et al. 2020)

The GC has a capillary column with a length of $30 \mathrm{~m}$ and a diameter of $0.32 \mathrm{~mm}$, and the furnace temperature of the $\mathrm{GC}$ oven was programmed between $40{ }^{\circ} \mathrm{C}$ and $320^{\circ} \mathrm{C}$ at a rate of $4{ }^{\circ} \mathrm{C} / \mathrm{min}$ and held at $320^{\circ} \mathrm{C}$ for $30 \mathrm{~min}$. As a result, $n$-alkanes distribution together with acyclic isoprenoids in the saturated hydrocarbon were identified and examined based on the peak heights in relation to the retention times.

\section{Results and discussion}

\section{API gravity and sulphur (S wt. \%) content}

Specific gravity and sulphur (S) content provide genetic information and classifies crude oils. Herein, specific gravity, API gravity, and S content values for the analyzed oils were measured and calculated (Table 1). The examined oils have moderate API gravity values between $23.55^{\circ}$ and $32.57^{\circ}$ (Table 1), suggesting that they are relatively light crude oil. These gravity values further suggest that the oils were generated from mature source rocks because API values increased with an increase in the degree of thermal maturity.

The sulphur (S) content in the examined oil samples was also measured and found to be between 0.18 and 0.23 weight percentage (Table 1). However, the $\mathrm{S}$ content is primarily measured as weight percentage and commonly used as an indicator for depositional conditions and degree of thermal maturity (e.g., Berner and Raiswell 1983). The relationship between the S content and API gravity of the oil samples was examined and indicates that the API values increased with decreasing sulphur (S) content (Fig. 4). Further, the low $\mathrm{S}$ contents were combined with API values and used to assess the difference between kerogen Type II and Type II-S (Orr 2001). In this relationship, the examined four oils were generated from source rock containing sulfur-poor Type II kerogen (Fig. 5).

\section{SARA composition}

The oil samples were fractionated into saturates, aromatics, resins and asphaltenes (SARA) and their relative proportions were measured (Table 1). The distributions of the SARA compositions show that the oils are dominated by a saturated fraction, with a volume of $73.49 \%-82.43 \%$. Significant amounts of aromatic $\mathrm{HC}$ are also present in the range of $9.54 \%-21.11 \%$ volume, followed by relatively small amounts of resins and asphaltenes in the range of $4.20 \%$ $11.56 \%$ and $0.65-2.68 \%$, respectively (Table 1 ). The relative percentages SARA composition of the samples are plotted in a ternary diagram of Tissot and Welte (1984), and suggest that the oil samples being analyzed are paraffinic oils (Fig. 6). In addition to high paraffinic materials, the highest saturate contents of the samples, with low polar components (i.e., resin and asphaltene) further suggests that the examined oils were generated from mature source rock, because the polar components decrease with thermal maturity. This inference is supported by the low content of sulphur (S) in the analyzed oils of less than 0.25 (Table 1).

\section{Vanadium (V) and nickel (Ni) trace metals}

Trace metal analysis was performed on the four examined oil samples, and showed that the $\mathrm{V}$ and $\mathrm{Ni}$ values of the oil samples range from 29 to $94 \mathrm{ppm}$ and $16 \mathrm{ppm}$ to $29 \mathrm{ppm}$,

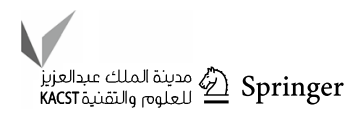




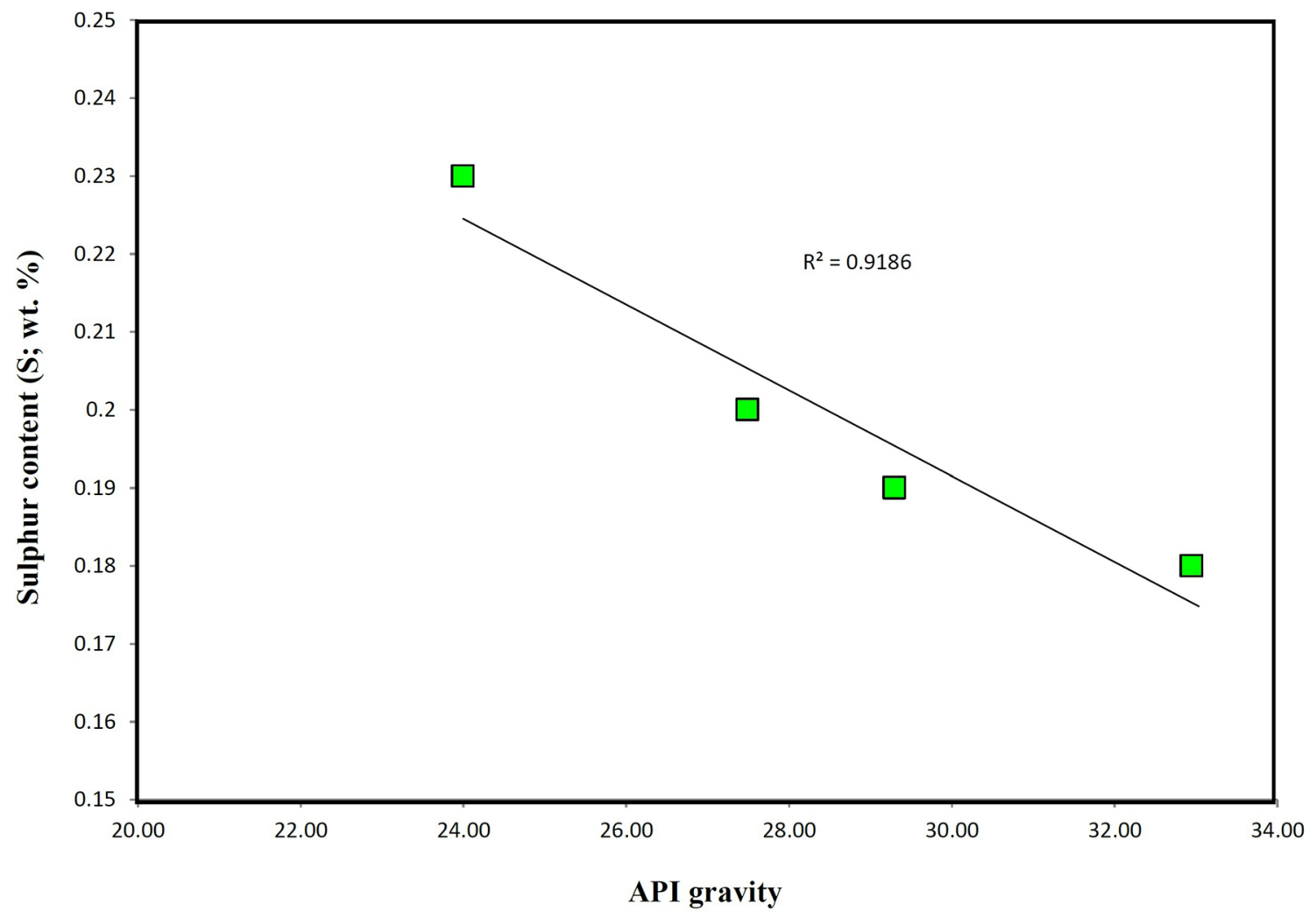

Fig. 4 Distribution of the sulfur content plotted against API gravity, showing a good correlation and indicates that the API values were increased with decreasing sulphur (S) content of the examined oils

respectively (Table 1). Such $\mathrm{V}$ and $\mathrm{Ni}$ trace elements are commonly found in the crude oils (e.g., Khuhawar et al. 2012; Akinlua et al. 2007; e.g., Vieira et al., 2016), and their $\mathrm{V} / \mathrm{Ni}$ and $\mathrm{V} /(\mathrm{V}+\mathrm{Ni})$ ratios used to provide information on redox environmental conditions during the deposition of the likely source rocks (Barwise 1990; Hatch and Leventhal 1992; Bechtel et al. 2001; Galarrage et al. 2008).

The highest values of $\mathrm{V} /(\mathrm{V}+\mathrm{Ni})$ ratio were commonly used as a good indicator of sediment deposition under highly euxinic conditions (Hatch and Leventhal 1992). Based on Hatch and Leventhal (1992) scale, the $\mathrm{V} /(\mathrm{V}+\mathrm{Ni})$ ratio between 0.54 and 0.84 indicates reducing environmental conditions, whereas $\mathrm{V} /(\mathrm{V}+\mathrm{Ni})$ ratio greater than 0.84 suggests highly euxinic conditions. Accordingly, the oil samples were generated from source rocks, depositing under reducing conditions as demonstrated by their $\mathrm{V} /(\mathrm{V}+\mathrm{Ni})$ ratios in the range of $0.55-0.85$ (Table 1). Three oil samples have low $\mathrm{V} /(\mathrm{V}+\mathrm{Ni})$ ratios in the range of $0.55-0.63 \%$, while other sample has the highest $\mathrm{V} /(\mathrm{V}+\mathrm{Ni})$ ratio of upto 0.85 (Table 1). The highest $\mathrm{V} /(\mathrm{V}+\mathrm{Ni})$ ratio of this oil sample suggests that the oil was generated from source rock deposited under more reducing than other samples.
In addition, the ratio of $\mathrm{V} /(\mathrm{V}+\mathrm{Ni})$ is also combined with sulphur (S) content and used to determine the paleoenvieromantal conditions and source of organic matter input of the possible source rocks (e.g., Barwise 1990; Wenger et al. 2002; Galarraga et al. 2008; Hakimi and Abdullah 2013). The $\mathrm{V} /(\mathrm{V}+\mathrm{Ni})$ ratios of more than 0.50 , with low $\mathrm{S}$ content of less than $1 \%$, further indicate that the analyzed oils were generated from source rock deposited under mainly suboxic conditions (Fig. 7).

The V/Ni ratio can also be used as indicators for redox conditions of their source rocks (Barwise 1990; Hatch and Leventhal 1992; Bechtel et al. 2001; Galarrage et al. 2008). Based on the Galarraga et al. (2008), the V/Ni ratio greater than 3 indicates that the sediments were deposited in a reducing environment, whereas $\mathrm{V} / \mathrm{Ni}$ ratios ranging from 1 to 3 indicate deposition under suboxic to oxic and the oxic conditions is represented at V/Ni ratio of less than 1. Following scale of Galarraga et al. (2008), the examined oils have values of $\mathrm{V} / \mathrm{Ni}$ ratio between 1.24 and 5.88, ranging from anoxic to relatively oxic conditions. Three examined oil samples with V/Ni ratios between 1.24-1.71 suggest source rock deposited under suboxic to relatively oxic conditions, whereas other sample has V/Ni ratio of more than 3 (5.88; Table 1) indicates more reducing environmental conditions, 


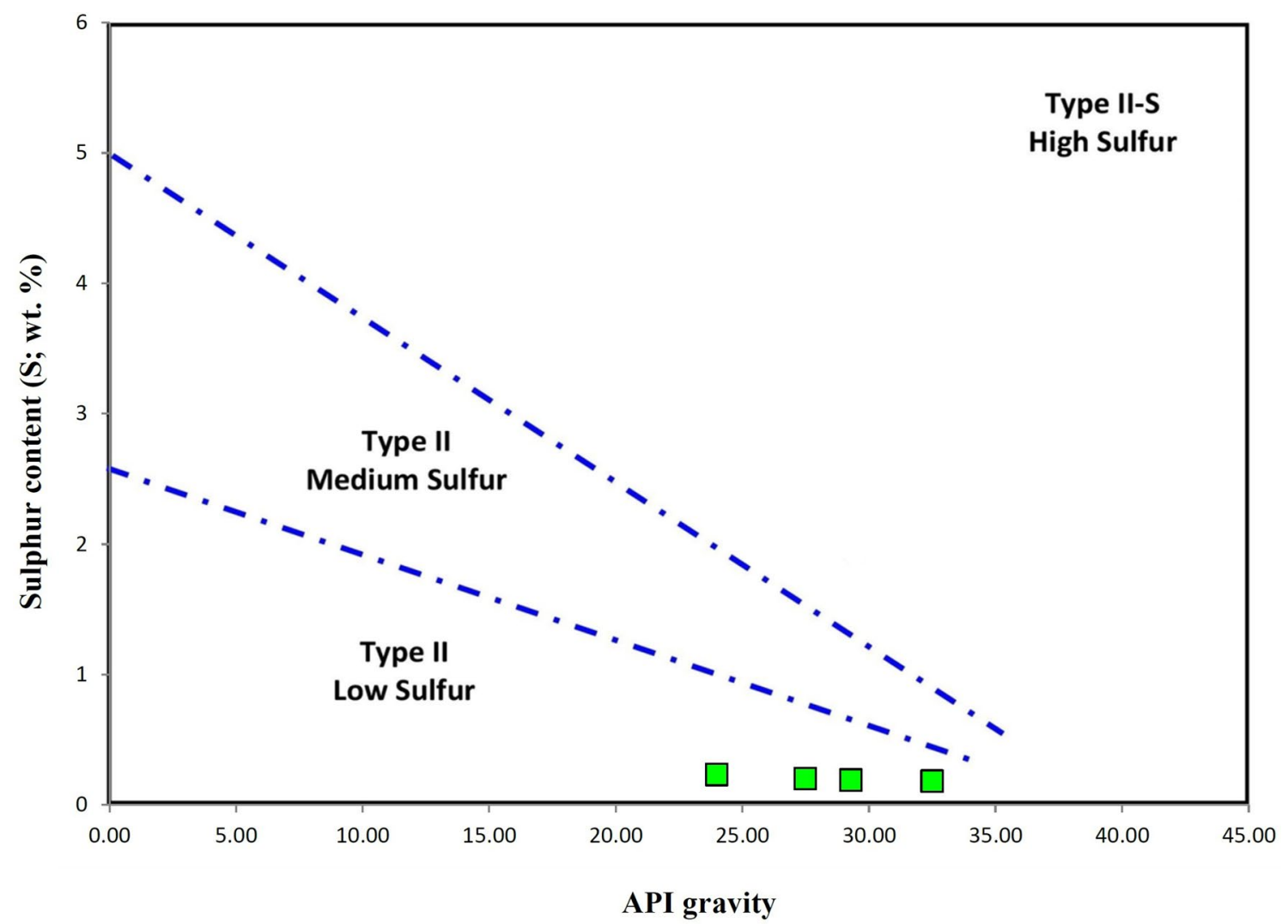

Fig. 5 Relationship between API gravity and sulphur content, showing that the examined oils were derived from kerogen Type II, with low sulphur content (modified after Orr 2001)

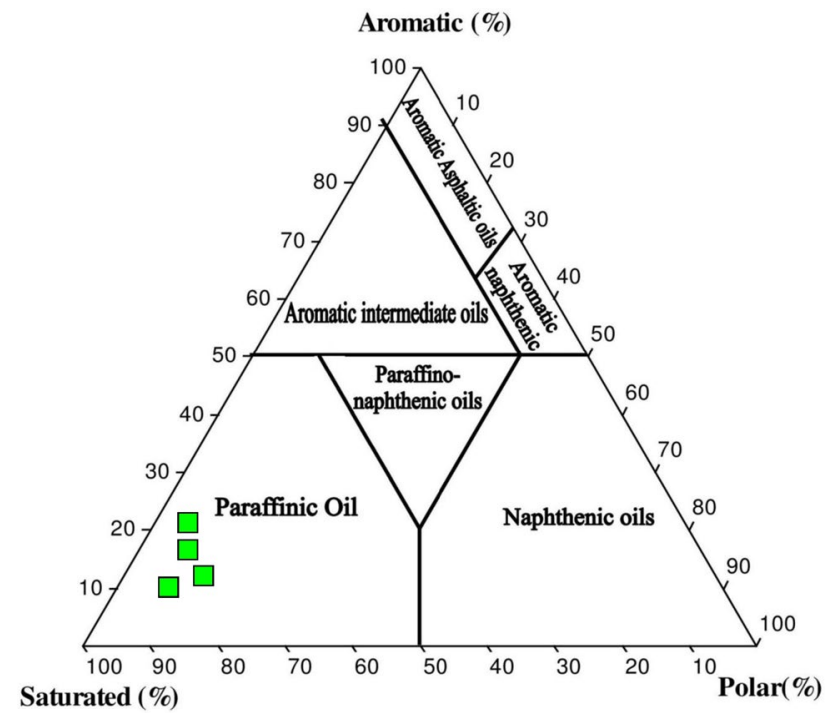

Fig. 6 Ternary plot of saturated and aromatic hydrocarbon fractions with polar components obtained in the analyzed oils, indicating that the analyzed samples are primarily paraffinic oils (modified after Tissot and Welte 1984) because the $\mathrm{V}$ element is usually enriched in anoxic (reducing) environmental conditions compared to $\mathrm{Ni}$ (Barwise 1990; Galarraga et al. 2008).

\section{Normal alkane and acyclic isoprenoid distributions and their interpretation to organic matter input and environmental conditions}

Data interpretation from the molecular composition of the organic matter, in particular, the normal alkane and acyclic isoprenoid distributions and their ratios and parameters can complement each other in interpreting the organic matter and its depositional environmental conditions (Peters et al. 2005; Hakimi and Abdullah 2013).

In the current work, the distributions of $n$-alkane and isoprenoid of the oil samples were obtained from GC chromatograms (Fig. 8), and their ratios and parameters are listed in Table 1.

The chromatograms of the examined oils show the bimodal distribution of medium to high molecular weight compounds within the range of $n-\mathrm{C}_{13}$ to $n-\mathrm{C}_{42}$, along with acyclic pristane and phytane isoprenoids (Fig. 8), suggesting that the oil samples are from source rock containing a mixed organic matter (Alias et al. 2012; Sarki Yandoka et al. 


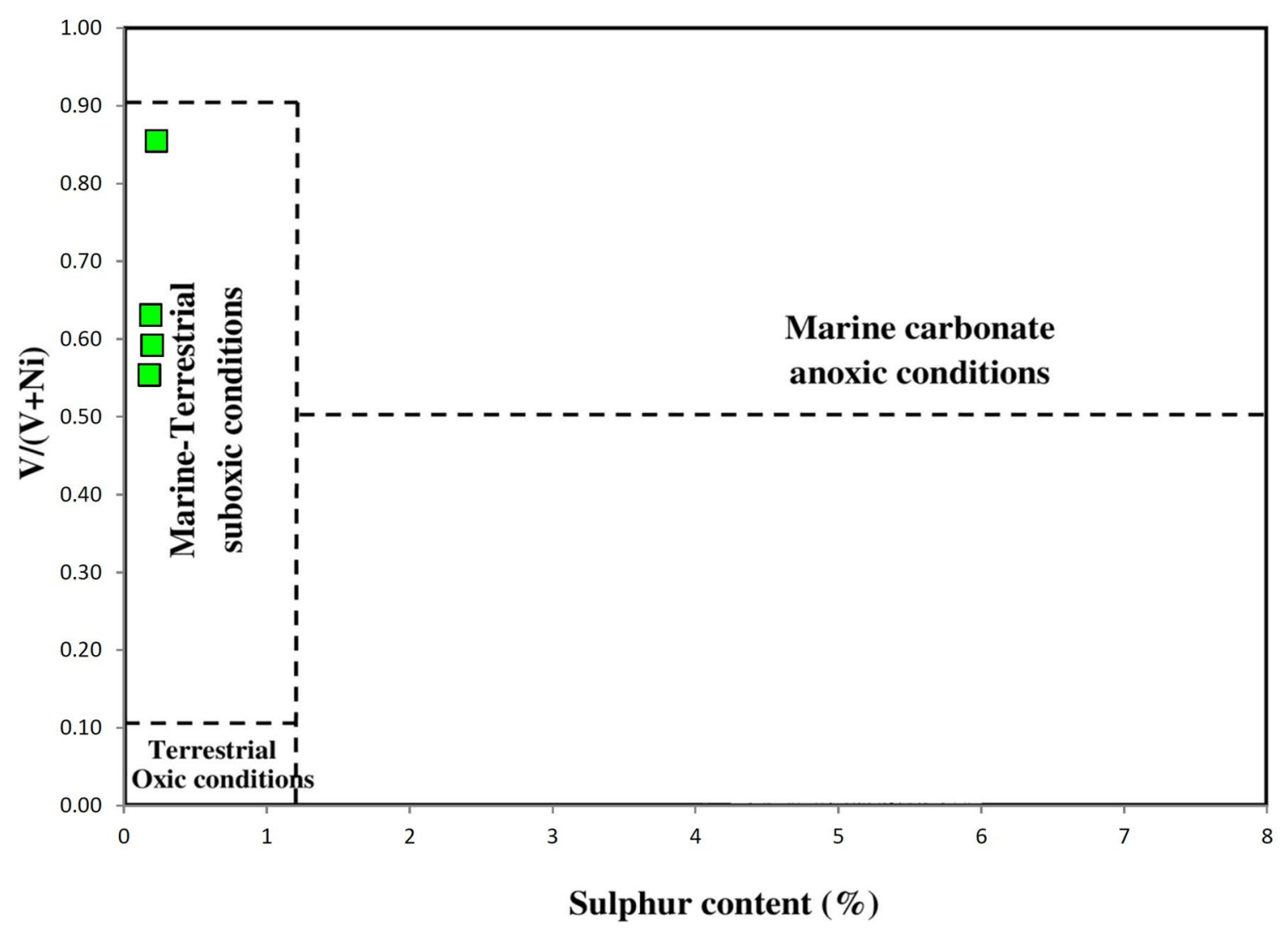

Fig. 7 Cross-plot of the sulphur (S) content combined with the vanadium (V) and nickel (Ni) metals ratios, showing that the examined oils were scoured from mixed marine and terrestrial organic matter deposited under suboxic conditions

2015a and b; Hakimi et al. 2014). The gas chromatograms of the most of oil samples $(n=3)$ display bimodal distribution, with high amounts of high molecular weight compounds $\left(n-\mathrm{C}_{29}\right.$ to $\left.n-\mathrm{C}_{40}\right)$ as shown in Fig. $8 \mathrm{~A}-\mathrm{C}$, suggesting a mixture of organic matter with high contributions of terrestrial organic matter input into their source rocks. Other sample is dominated by $\mathrm{C}_{15}$ to $\mathrm{C}_{25}$ carbon number of the normal alkanes in the gas chromatograms (Fig. 8D), suggesting high abundance of aquatic organic matter derived from algal and microbial mats (Hakimi et al. 2020; Al-Khafaji et al. 2021; Hadad et al. 2021; Gharib et al. 2021).

The dominance of a mixed organic matter input is also consistent with low carbon preference index (CPI) values between 0.90 and 1.05 (Table 1). The degree of waxiness was determined using the following equation: Waxiness degree $=\Sigma\left(n-\mathrm{C}_{21}-n-\mathrm{C}_{31}\right) / \Sigma\left(n-\mathrm{C}_{15}-n-\mathrm{C}_{20}\right)$. The waxiness level of the oil samples is $0.87-2.50$, further suggesting the presence of a mixed organic matter. However, the three analyzed samples have relatively higher values of waxiness degree (1.66-2.50) compared with other oil sample, indicating that these three oils are more waxy oils than other sample and their source rock received high contributions of terrestrial organic matter, as the relative abundance of waxiness level is typically indicative of organic matter derived from land plants (Connan and Cassou 1980; Johns 1986). However, the presence of high waxy materials in these oils can case several operational problems during production, storage and transportation through pipelines.

In addition to $n$-alkanes, the chromatograms of the oil samples are distinguished by a significant amount of acyclic isoprenoid HCs, i.e., pristane (Pr) and phytane (Ph) (Fig. 8). $\mathrm{Pr}$ is greater than $\mathrm{Ph}$ (Fig. 8), with a $\mathrm{Pr} / \mathrm{Ph}$ ratio of 1.61-2.17 (Table 1). The isoprenoid ratio provides information about the paleodepositional environment as an indicator of redox conditions (Didyk et al. 1978; Ten Haven et al. 1987; Chandra et al. 1994; Peters et al. 2005; Tserolas et al. 2019). The $\mathrm{Pr} / \mathrm{Ph}$ ratio of the oil samples $(1.61-2.17)$ indicates that the source rocks for the oil samples were deposited in transitional environments and generally preserved under suboxic to relatively oxic depositional conditions. The $\mathrm{Pr} / \mathrm{Ph}$ values of more than 2 (2.09-2.17) suggest relatively oxic environmental conditions, whereas other one oil sample with lowest $\mathrm{Pr} / \mathrm{Ph}$ ratio of 1.61 suggest more reducing (suboxic) conditions during deposition its source rock. Isoprenoid ratios relative to $n$-alkane concentrations $\left(\mathrm{C}_{17}-\mathrm{C}_{18}\right)$ were also measured as $\mathrm{Pr} / n-\mathrm{C}_{17}$ and $\mathrm{Ph} / n-\mathrm{C}_{18}$ ratios and they are in the range of $0.55-1.30$ and $0.24-0.93$, respectively (Table 1 ). These isoprenoid ratios further suggest that oil samples were 

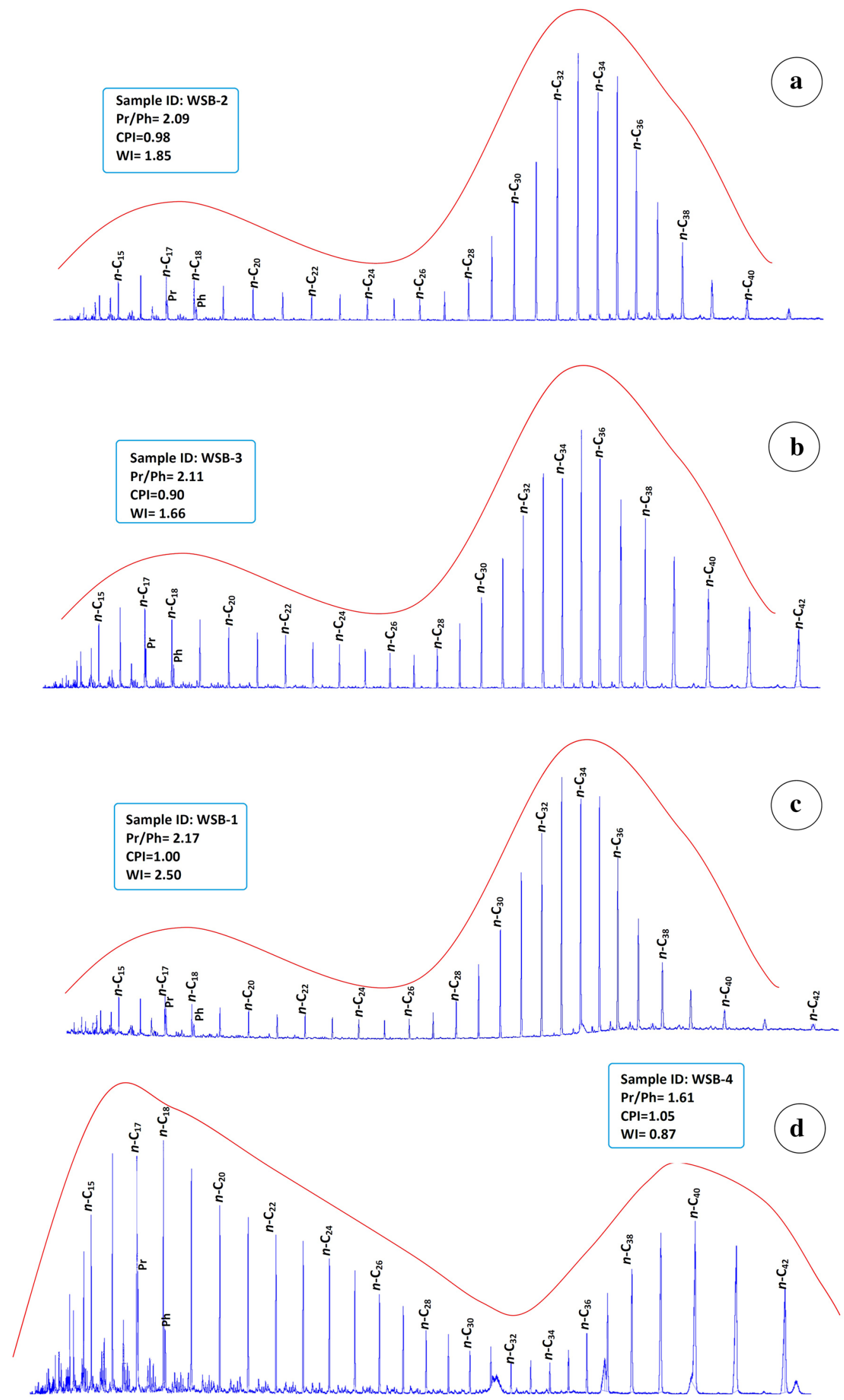

Fig. 8 Gas chromatograms of the saturated hydrocarbon fraction for three oil samples analyzed, showing a complete suite of n-alkanes and acyclic isoprenoids (e.g., pristane and phytane), indicating that there is no biodegradation in the analyzed samples 
obtained from source rock containing a mixture of organic matter and deposited in transitional environments (Fig. 9A and $\mathrm{B}$ ). The isoprenoid $\mathrm{Pr} / \mathrm{Ph}$ ratio, CPI parameter and waxiness degree further support a mixture of organic matter input in the source rocks (Fig. 10).

\section{Oil characteristics and their relevance to biodegradation and maturity}

Biodegradation is the mechanism that influences the most of the world's oils and their geochemical properties. Therefore, the exploration of oil samples is affected by the high costs of refining biodegraded oils.
Fig. 9 Geochemical biomarker results of the analyzed oil samples: a Pristane $/ n-\mathrm{C}_{17}$ versus phytane $/ n-\mathrm{C}_{18}$ (from Shanmugam 1985) and b pristane/ phytane versus pristane $/ n-\mathrm{C}_{17}$, indicating that the examined oils were generated from source rocks contained a mixture organic matter

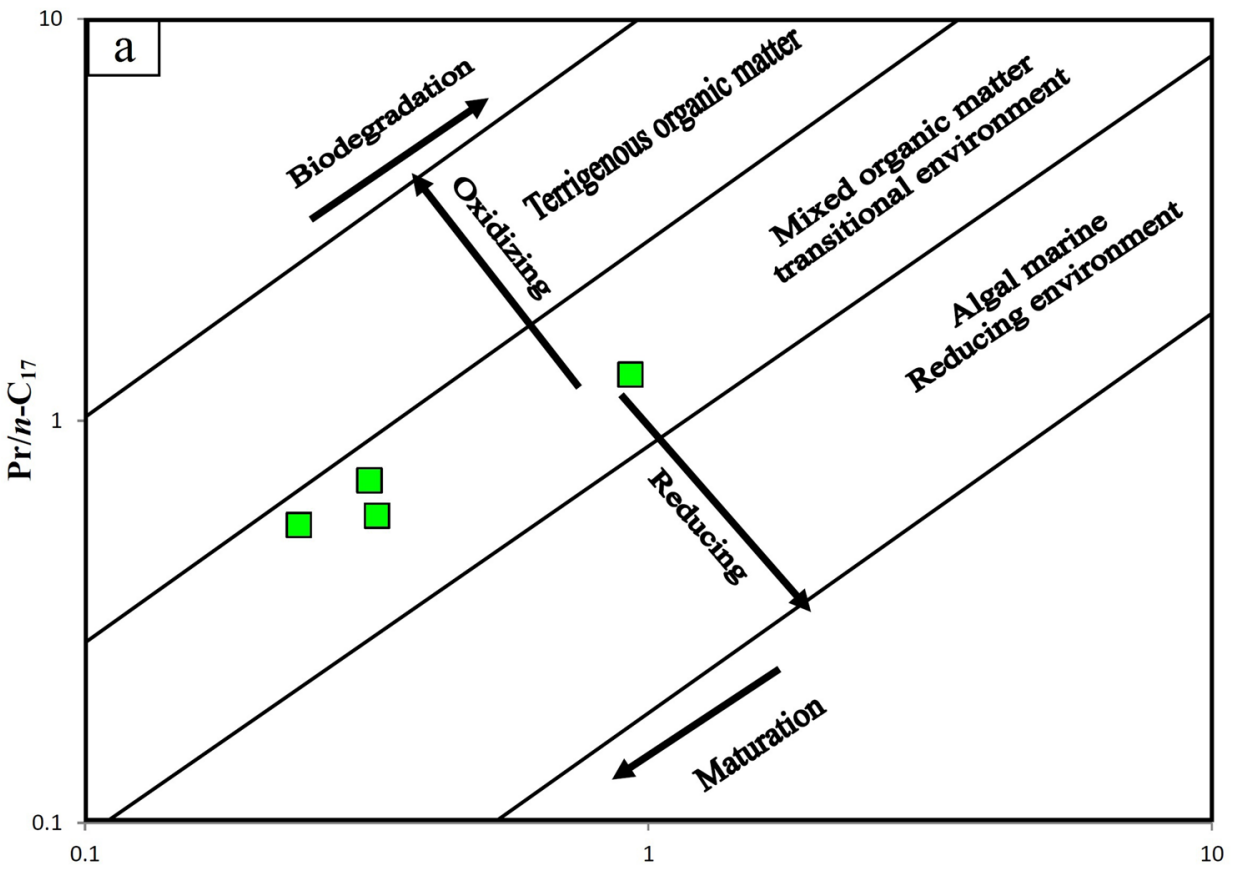

$\mathrm{Ph} / n-\mathrm{C}_{18}$

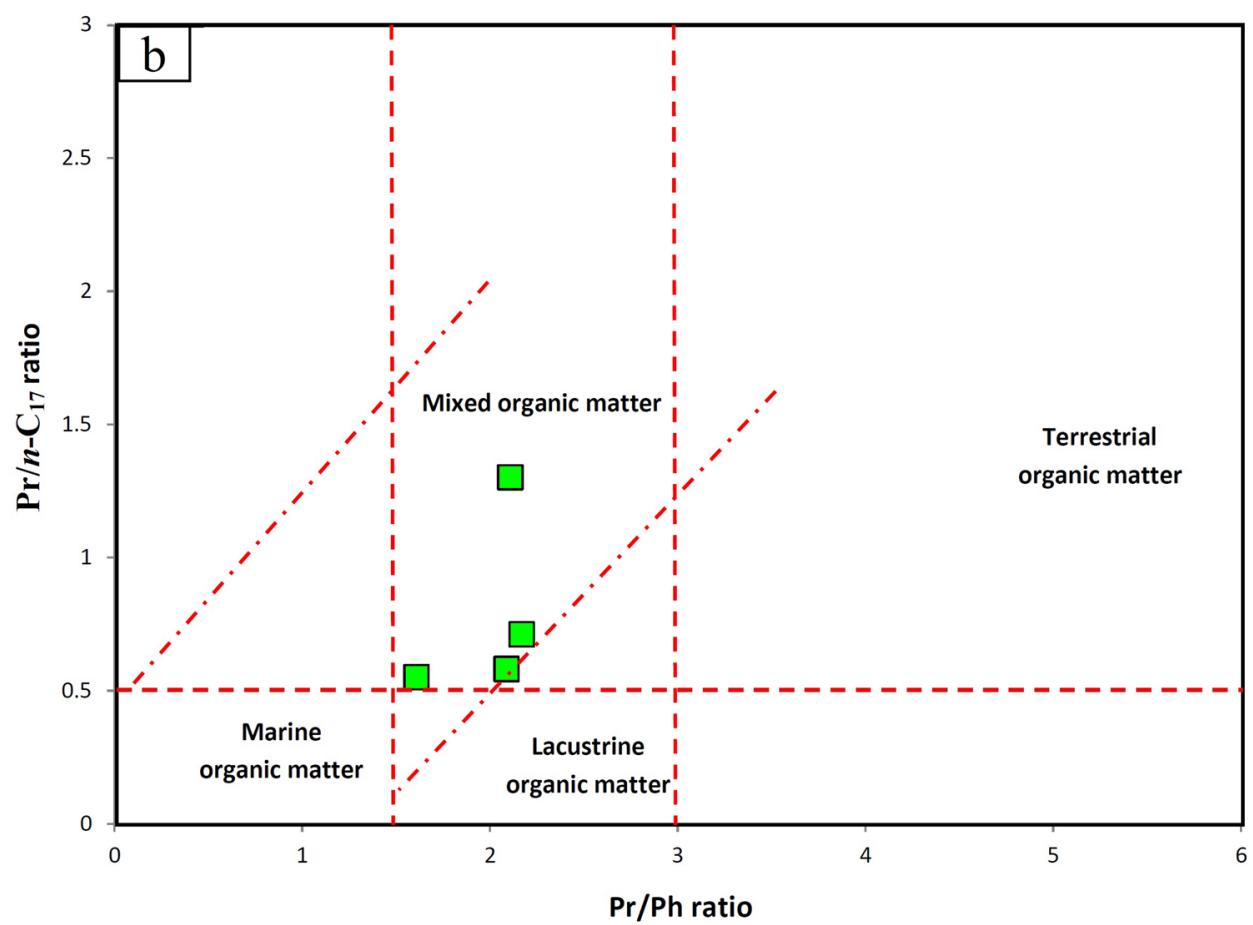


Fig. 10 Geochemical biomarker results of the analyzed oil samples: a pristane/phytane versus CPI and $\mathbf{b}$ pristane/phytane versus waxiness degree, further indicating that the examined oils were generated from source rocks contained a mixture organic matter
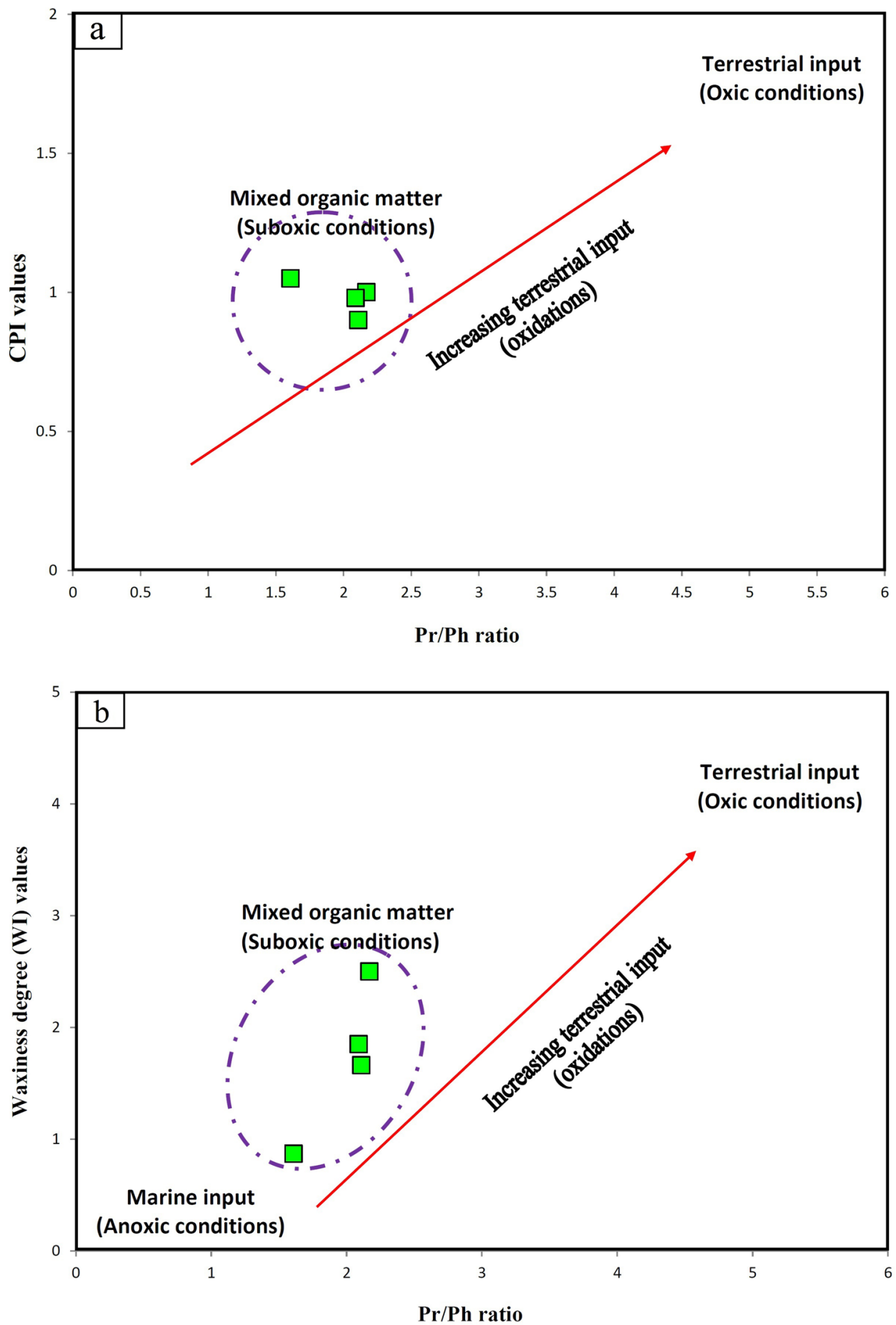

The physical properties and chemical compositions of the fresh oils were changed during the biodegradation processes (e.g., Palmer 1993; Peters et al. 2005).

Biodegraded oils have lower API gravity and higher viscosity values and contain relatively higher amounts of NSO (i.e., resin and asphaltene) compounds compared to fresh oil (e.g., Barth et al. 2004; Luo and Gu 2005 and 2007). The oils containing heavy asphaltic materials are heavy in this respect and generally more degraded than oils rich in saturated and aromatic HCs (Connan 1984; Larter, et al. 2003, 2005; Al-Khafaji et al. 2020).

In addition to physical properties and chemical compositions, several studies have reported that the level of biodegradation is shown by the abundance and distributions of normal alkane and acyclic isoprenoids on gas chromatograms and the shape of baselines of the chromatograms 
(Connon 1984; Head et al. 2003; Peters et al. 2005). Light normal alkanes and acyclic isoprenoids can be removed in the early stage of biodegradation of oil, whereas heavy branched and cyclic saturated HCs, as well as aromatics are the most resistant HCs to biodegradation (Larter et al. 2005).

Herein, the observed geochemical and physical properties of the oil samples indicate the occurrence of biodegradation. The physical properties indicate that the oil samples are not heavy but light oils, thus, they were not biodegraded. The relatively high API gravity of greater than $22^{\circ}$ indicates the absence of biodegradation (Wang et al. 2021).

The SARA composition of the oil samples in which the high abundance of saturated and aromatic hydrocarbons compared with small amounts of resin and asphaltene compounds (Table 1) further indicates the absence of biodegradation. In addition to biodegradation, the high saturate/ aromatic ratios of more than 3 (Table 1) also signifies that the water washing in bulk composition did not affect the oil samples (Wang et al. 2021).

Furthermore, the biodegradation of the oil samples was assessed using the distribution of normal alkanes and acyclic isoprenoids (Connon 1984; Head et al. 2003; Peters et al. 2005; Larter et al. 2005). Thee chromatograms of the oil samples are represented high abundance of $n$-alkanes $\left(\mathrm{C}_{13}\right.$ to $n$ - $\left.\mathrm{C}_{42}\right)$, with a straight baseline (Fig. 8), further suggesting the absence of evidence for biodegradation.
The degree of maturation for the oil samples was assessed using the SARA composition and API gravity and S content. The bulk oil composition (SARA) can also be used to predict the thermal maturity of their possible source rocks (Killops et al 1998; Peters et al. 2005). A relatively high content of polar components (resins and asphaltenes) indicates low maturity of source rock, because polar components decrease with the thermal maturity (e.g., Killops et al. 1998; Egbo et al. 2020; Peters et al. 2005).

Herein, the oil samples showed high saturated HC compared with other heavy components of aromatic and polar (resin and asphaltene), indicating that the oils were generated from a mature source rocks, corresponding to the VRo values of more than $0.90 \%$ as demonstrated by the plots of the saturate, aromatic, and polar portions on the Tissot and Welte (1984) diagram (Fig. 11). The mature stage of the probable source rocks is also consistent with the moderate to high API gravity and low S content of less than $1 \%$ (Table 1). However, the API gravity and S content are also plotted with the SARA composition in order to reveal the relationships and help to give information of the degree of thermal maturation for examined oils. These correlations showed positive relations between the saturated fraction and API gravity and the S content with other fractions (Fig. 12a and b), and negative relations between the saturated fraction and S content and the API gravity with other
Fig. 11 Ternary diagram showing the gross composition (saturated and aromatic hydrocarbons as well as polar) of the analyzed oils, suggesting high mature oils (modified after Peters et al. 2005)

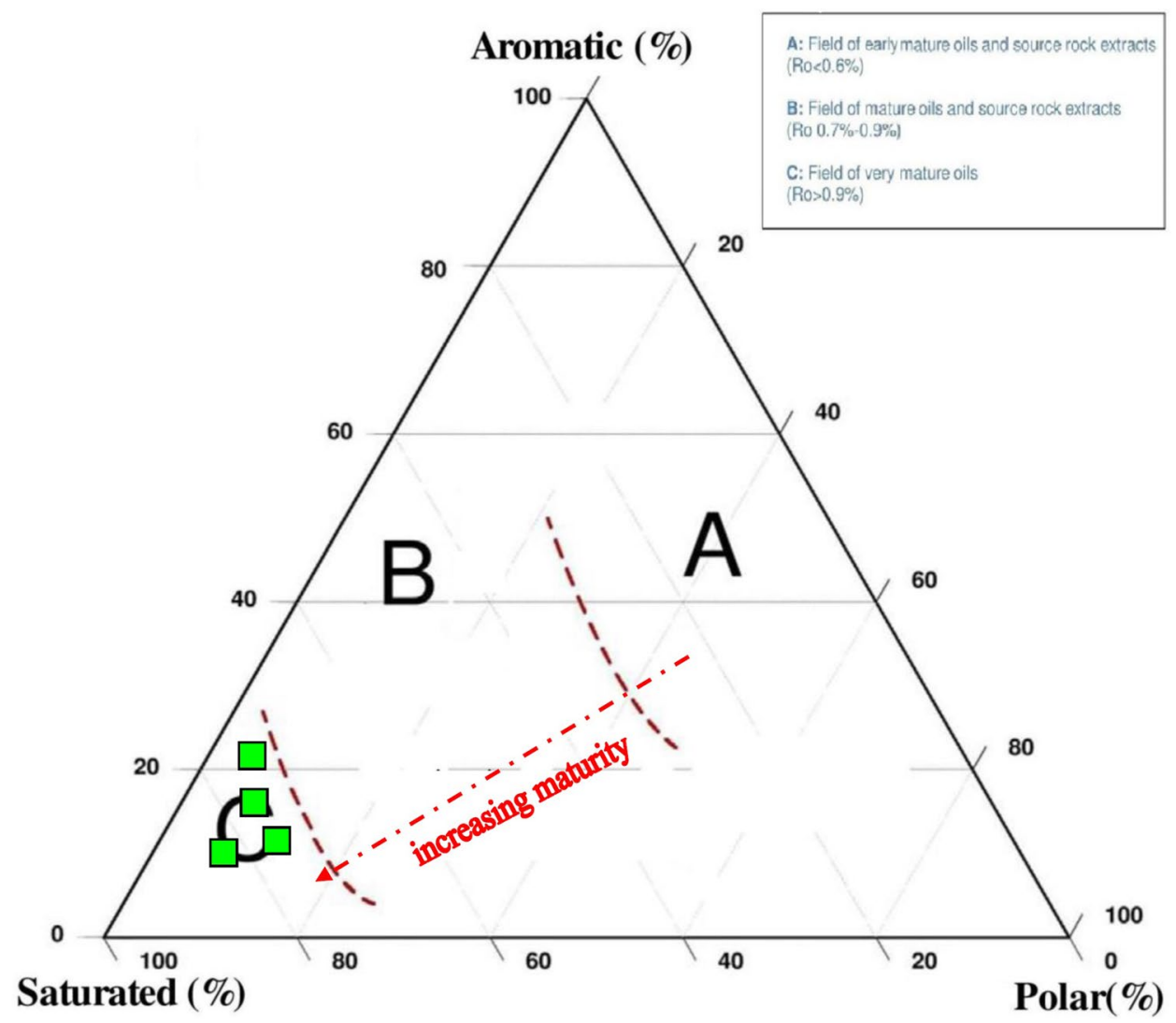


fractions (Fig. 12c and d). Therefore, the proportion of saturated HCs and API increased with maturity, whereas the other heavy HCs (aromatic) and non-HCs (resin + asphaltene) as well as $\mathrm{S}$ content decreased with maturity.

Furthermore, the CPI values derived from the distribution of normal alkanes were also used to evaluate the thermal maturation of the analyzed oils and their source rocks. Although CPI is affected by source facies (Peters et al. 2005), it was used as an indicator of thermal maturity (Bray and Evans 1961). According to Bray and Evans (1961), CPI decreases with an increase in thermal maturity, with values close to unity, indicating mature source rocks (Bray and Evans 1961). Consistent with previous SARA composition, the CPIs range of the oil samples was between 0.90 and 1.05 , and further suggest that the oils were generated from mature source rocks.
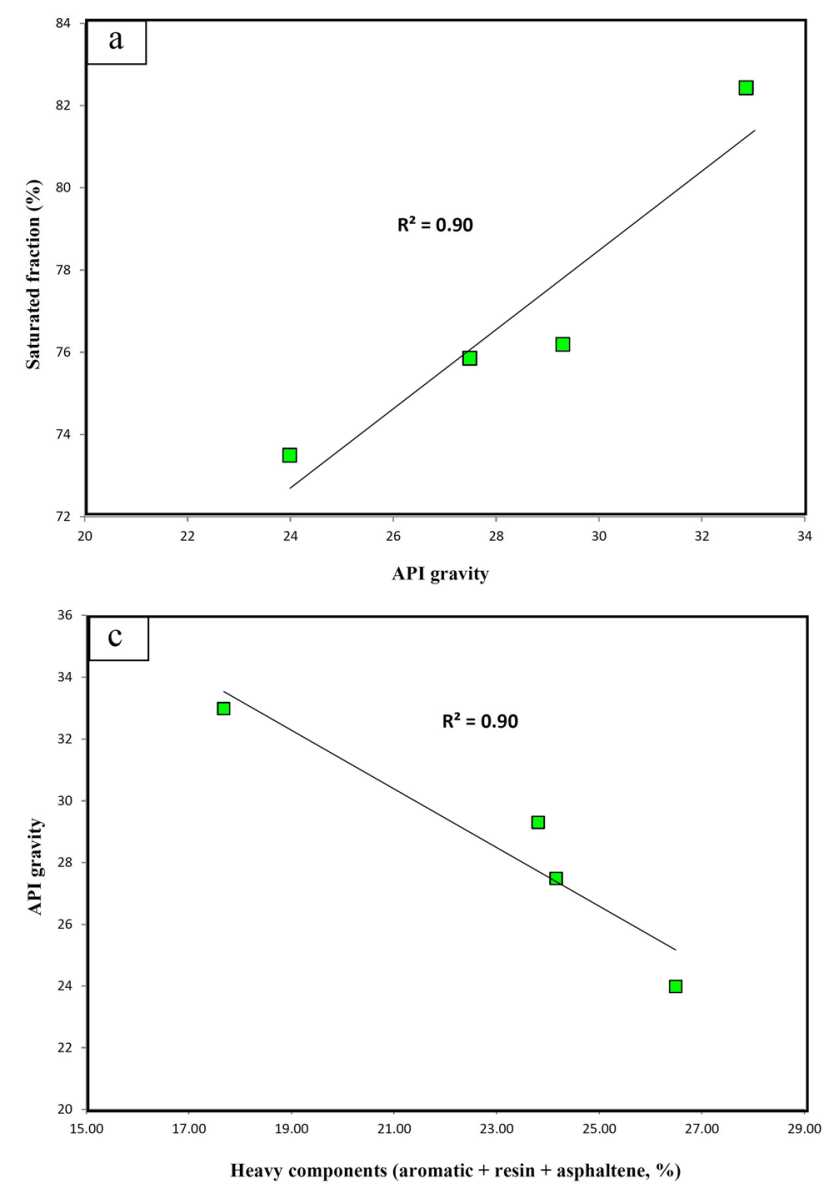

\section{Conclusions}

In this paper, the geochemical and physical characteristics of oil samples collected from oilfields in the western Siberian Basin were investigated using several methods. The results of this paper were used to discuss the characteristics of source rocks, including organic matter source input, depositional environment conditions and thermal maturity based on the obtained geochemical and physical properties. Based on the obtained results, the following conclusions are drawn:

1. The oil samples are likely to be relatively light oils, with high content of paraffinic materials as indicated from moderate API gravities $\left(23.55^{\circ}-32.57^{\circ}\right)$, and high content of saturated $\mathrm{HC}$ fraction of more than $70 \%$. The API gravity and high aliphatic $\mathrm{HC}$ also indicate that oil samples were generated from mature source rocks.

2. The oil samples were generated from source rock containing low sulfur Type II kerogen and deposited under mainly suboxic conditions. This finding is demonstrated
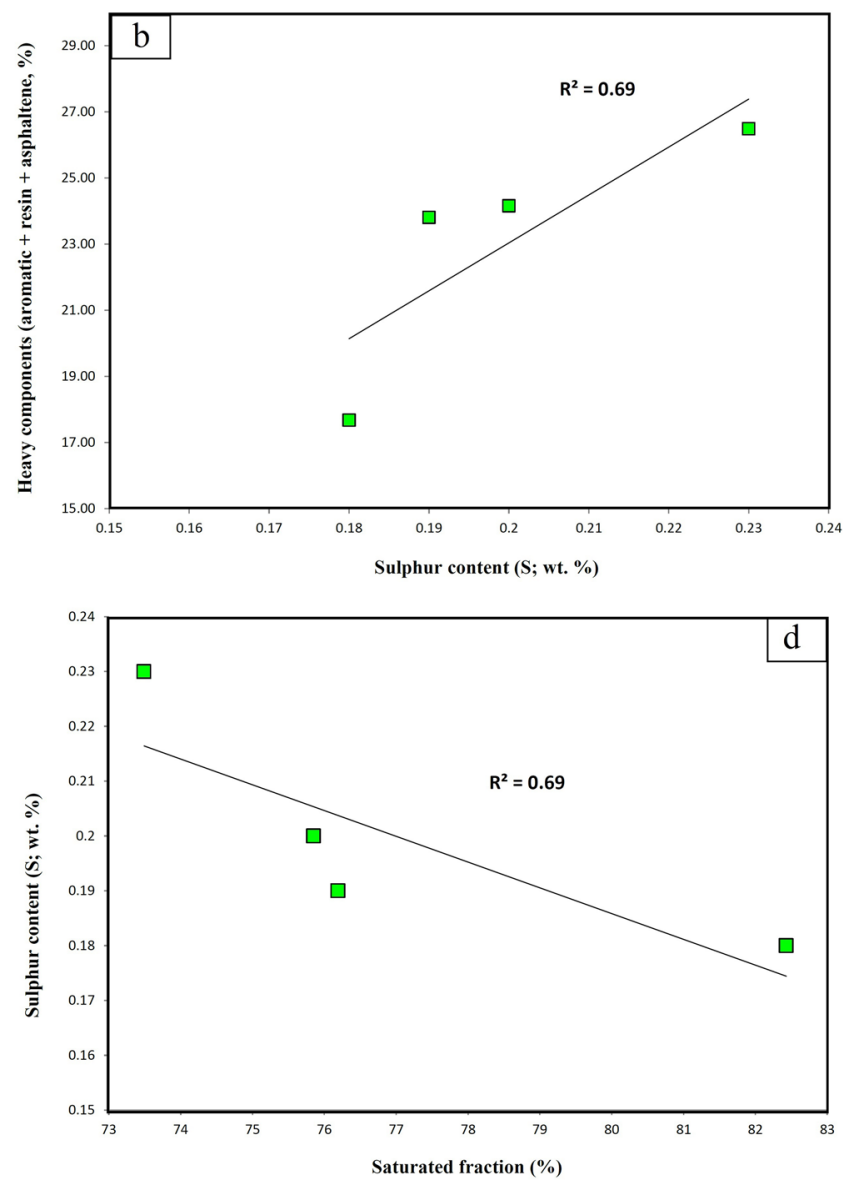

Fig. 12 Cross-plots of API gravity and sulphur content versus SARA composition of the analyzed oil samples, and the correlations indicate that the analyzed oils are thermally mature 
by the combination between physical results of API gravity and geochemical results of the $\mathrm{S}, \mathrm{V}$ and Ni elements and their ratios.

3. The distribution of normal alkanes and acyclic isoprenoids also suggests that the oil samples were generated from source rocks contained a mixture organic matter deposited under suboxic to relatively oxic environmental conditions.

4. Both SARA composition and hydrocarbon distributions of normal alkane and acyclic isoprenoids suggest that the examined oils have not alterated by biodegradation or water washing processes during accumulation.

5. In terms of maturity, the examined oils were generated from mature source rock as indicated from both physical and geochemical parameters.

Acknowledgements This work was supported by the Ministry of Science and Higher Education of the Russian Federation under agreement No. 075-15-2020-931 within the framework of the development program for a world-class Research Center "Efficient development of the global liquid hydrocarbon reserves". The authors also extend their sincere appreciation to the Researchers Supporting Project number (RSP-2021/92), King Saud University, Riyadh, Saudi Arabia. The constructive comments by anonymous reviewers have improved the original manuscript are gratefully acknowledged.

Funding The authors received no financial support for the research, authorship, and/or publication of this article.

\section{Declarations}

Conflict of interest statement On behalf of all authors, the corresponding author states that there is no conflict of interest.

Open Access This article is licensed under a Creative Commons Attribution 4.0 International License, which permits use, sharing, adaptation, distribution and reproduction in any medium or format, as long as you give appropriate credit to the original author(s) and the source, provide a link to the Creative Commons licence, and indicate if changes were made. The images or other third party material in this article are included in the article's Creative Commons licence, unless indicated otherwise in a credit line to the material. If material is not included in the article's Creative Commons licence and your intended use is not permitted by statutory regulation or exceeds the permitted use, you will need to obtain permission directly from the copyright holder. To view a copy of this licence, visit http://creativecommons.org/licenses/by/4.0/.

\section{References}

Afanasyev SA, Bukreeva GF, Vakulenko AS, Mosina OA (1993) Typification of the JK10 horizon sections of the Talinskoye deposit according to macro-heterogeneity character: Russian. Geol Geophys 34:36-40

Akinlua A, Ajayi TR, Adeleke BB (2007) Organic and inorganic geochemistry of Northwestern Niger Delta. Geochem J 41:271-281

Alias FL, Abdullah WH, Hakimi MH, Azhar MH, Kugler RL (2012) Organic geochemical characteristics and depositional environment of the Tertiary Tanjong Formation coals in the Pinangah area, onshore Sabah. Malaysia Int J Coal Geol 104:9-21

Al-Khafaji AJ, Hakimi MH, El-Khedr Ibrahim EK, Najaf AA, Al Faifi H, Lashin A (2020) Organic geochemistry of oil seeps from the Abu-Jir Fault Zone in the Al-Anbar Governorate, western Iraq: Implications for early-mature sulfur-rich source rock. J Petrol Sci Eng 184:1-16

Al-Khafaji AJ, Hakimi MH, Mohialdeen IMJ, Idan RM, Afify WE, Lashin A (2021) Geochemical characteristics of crude oils and basin modelling of the probable source rocks in the Southern Mesopotamian Basin, South Iraq. J Pet Sci Eng 196:107641

Al-Muntaser AA, Varfolomeev MA, Suwaid MA, Yuan C, Chemodanov AE, Feoktistov DA, Rakhmatullin IZ, Abbas M, Domínguez-Álvarez E, Akhmadiyarov AA (2020) Hydrothermal upgrading of heavy oil in the presence of water at subcritical, near-critical and supercritical conditions. J Pet Sci Eng 184:106592

Barth T, Høiland S, Fotland P, Askvik KM, Pedersen BS, Borgund AE (2004) Acidic compounds in biodegraded petroleum. Org Geochem 35:1513-1525

Barwise AJG (1990) Role of nickel and vanadium in petroleum classification. Energy Fuels 4:647-652

Bechtel A, Gratzer R, Sachsenhofer RF (2001) Chemical characteristics of Upper Cretaceous (Turonian) jet of the gosau group of gams/ hieflau (styria, Austria). Int J Coal Geol 46:27-49

Belkin VI, Bachurin AK (1991) The structure and origin of highly permeable reservoir rocks in the basal beds of the Jurassic in the Tallinskoye field: Transactions of the USSR Academy of Sciences. Earth Sci Sect 310:102-104

Berner RA, Raiswell R (1983) Burial of organic carbon and pyrite sulphur in sediments over Phanerozoic time: a new theory. Geochim Cosmochim Acta 47:855-862

Bray EE, Evans ED (1961) Distribution of $n$-paraffins as a clue to recognition of source beds. Geochim Cosmochim Acta 22:2-15

Chandra K, Mishra CS, Samanta U, Gupta A, Mehrotra KL (1994) Correlation of different maturity parameters in the AhmedabadMehsana block of the Cambay basin. Org Geochem 21:313-321

Connan J (1984) Biodegradation of crude oils in reservoirs. In: Brooks J, Welte DH (eds) Advances in Petroleum Geochemistry. Academic Press, London, pp 299-335

Connan J, Cassou AM (1980) Properties of gases and petroleum liquids derived from terrestrial kerogen at various maturation levels. Geochim Cosmochim Acta 44:1-23

Didyk BM, Simoneit BRT, Brassell SC, Eglinton G (1978) Organic geochemical indicators of palaeoenvironmental conditions of sedimentation. Nature 272:216-222

Egbo OK, Adeigbe OC, Esegbue O (2020) Preliminary geochemical investigation of some crude oils from the Niger Delta Basin Nigeria. J Res Environ Earth Sci 6:18-25

Galarraga F, Reategui K, Martïnez A, Martínez M, Llamas JF, Márquez $\mathrm{G}(2008) \mathrm{V} / \mathrm{Ni}$ ratio as a parameter in palaeoenvironmental characterisation of non-mature medium-crude oils from several Latin American basins. J Pet Sci Eng 61:9-14

Gharib AF, Özkan AM, Hakimi MH, Zainal Abidin N, Lashin A (2021) Integrated geochemical characterization and geological modeling of organic matter-rich limestones and oils from Ajeel Oilfield in Mesopotamian Basin Northern Iraq. Marine Pet Geol 126:104930

Hadad YT, Hakimi MH, Abdullah AH, Kinawy M, El Mahdy O, Lashin A (2021) Organic geochemical characteristics of Zeit source rock from Red Sea Basin and their contribution to organic matter enrichment and hydrocarbon generation potential. J Afr Earth Sci 177:104151

Hakimi MH, Abdullah WH (2013) Geochemical characteristics of some crude oils from Alif Field in the Marib-Shabowah Basin, and source-related types. Mar Pet Geol 45:304-314 
Hakimi MH, Abdullah WH, Al Areeq NM (2014) Organic geochemical characteristics and depositional environments of the Upper Cretaceous coals in the Jiza-Qamar Basin of eastern Yemen. Fuel 118:335-347

Hakimi MH, Ahmed A, Kahal AY, Hersi OS, Al Faifi HJ, Qaysi S (2020) Organic geochemistry and basin modeling of Late Cretaceous Harshiyat Formation in the onshore and offshore basins in Yemen: Implications for effective source rock potential and hydrocarbon generation. Mar Pet Geol. https://doi.org/10.1016/j. marpetgeo.2020.104701

Hatch JR, Leventhal JS (1992) Relationship between inferred redox potential of the depositional environment and geochemistry of the Upper Pennsylvanian (Missourian) Stark Shale Member of the Dennis Limestone, Wabaunsee County, Kansas, USA. Chem Geol 99:65-82

Head IM, Jones DM, Larter SR (2003) Biological activity in the deep subsurface and the origin of heavy oil. Nature 426:344-352

Johns RB (1986) Biological markers in the sedimentary record. Elsevier, Amsterdam

Khuhawar MY, Mirza MA, Jahangir TM (2012) Determination of metal ions in crude oils. Crude Oil Emuls-Compos Stabil Charact 1:121-144

Killops SD, Funnell RH, Suggate RP, Sykes R, Peters KE, Walters C, Woolhouse AD, Weston RJ, Boudou JP (1998) Predicting generation and expulsion of paraffinic oil from vitrinite-rich coals. Org Geochem 29:1-21

Kontorovich AE, Ivanov IA, Koveshnikov AE, Krasnov VI, Perozio GN (1991) Geologic conditions of oil and gas productivity in the upper part of the Paleozoic sequence of West Siberia. In: Surkov VS, Kontorovich AE (eds) Theoretical and regional problems of oil and gas geology (Teoreticheskie i regionalnye problem geologii nefti i gaza): Novosibirsk. Nauka, Russia, pp 152-171

Kontorovich AE, Moskvin VI, Bostikov OI, Danilova VP, Fomin AN, Fomichev AS, Kostyreva EA, Melenevsky VN (1997) Main oil source formations of the West Siberian basin. Pet Geosci 3:343-358

Larter S, Wilhelms A, Head I, Koopmans M, Aplin A, di Primio R, Zwach C, Erdmann M, Telnaes N (2003) The controls on the composition of biodegraded oils in the deep subsurface-Part 1: biodegradation rates in petroleum reservoirs. Org Geochem 34:601-613

Larter SR, Head IM, Huang H, Bennett B, Jones M, Aplin AC, Murray A, Erdmann M, Wilhelms A, Di Primio R (2005) Biodegradation, gas destruction and methane generation in deep subsurface petroleum reservoirs: an overview. A.G. Dore, B. A. Vining (Eds.), Petroleum Geology: Northwest Europe and Global Perspectives: Proceedings of the 6th Petroleum Geology Conference, Geological Society, London, pp 633-640

Lopatin NV, Emets TP, Simonenkova OI, Galushkin YuI (1997) Source rocks for oils in the weathering crust and top of the Paleozoic basement in fields of the Middle Ob region: Geologiya. Geofizikai Razrabotka Neftyanykh Mestorozhdeniy, 7:7-22

Lopatin NV, Emets TP, Simonenkova OI, Erben JP (1998) Bazhenov petroleum-generation and accumulation system in the western Khantey anteclise: Geologiya. Geofizika i Razrabotka Neftyanykh Mestorozhdeniy, 5:2-27

Luo P, Gu Y (2005) Effects of asphaltene content and solvent concentration on heavy-oil viscosity. SPE/PS-CIM/CHOA international thermal operations and heavy oil symposium, Calgary (2005), pp 1-3

Luo P, Gu Y (2007) Effects of asphaltene content on the heavy oil viscosity at different temperatures. Fuel 86:1069-1078

Orr WL (2001) Evaluating kerogen sulfur content from crude oil properties. In: Isaacs CM, Rullkotter J (eds) The monterey formation from rocks to molecules. Columbia University Press, New York, pp 348-367

Palmer SE (1993) Effect of biodegradation and water washing on crude oil composition. Org Geochem 23:511-533

Peters KE, Kontorovich AE, Moldowan JM, Andrusevich VE, Huizinga BJ, Demaison GJ, Stasova OF (1993) Geochemistry of selected oils and rocks from the central portion of the West Siberian basin, Russia. Am Assoc Pet Geol Bull 77:863-887

Peters KE, Walters CC, Moldowan JM (2005) The Biomarker Guide, 2nd edn. Cambridge University Press, Cambridge, p 1155

Petrov Al A (1994) Biomarkers and geochemical conditions of oil generation in Russia. Geologiya Nefti i Gaza 6:13-18

Pyatkov MI, Pitkevich VP, and Yu KT (1988) Composition of vuggy and porous rocks of the Talin field and their relation to reservoir properties. In: Medvedsky RI, ed., Physico-lithological characteristics and reservoir properties of productive, deeply buried rocks of West Siberia (Fiziko-litologicheskiye osobennosti i kollektorskiye svoystva productivnykh porod glubokikh gorizontov Zapadnoy Sibiri): Tyumen, Russia, ZapSibNIGNI, p 128-135

Rudkevich MY, Ozeranskaya LS, Chistyakova NF, Kornev VA, Maksimov EM (1988) Petroleum-productive complexes of the West Siberian basin (Neftegazonosnye kompleksy Zapadno-Sibirskogo basseyna): Moscow, Nedra, p 304

Sarki Yandoka BM, Abdullah WH, Abubakar MB, Hakimi MH, Mustapha KA, Adegoke AK (2015a) Organic geochemical characteristics of Cretaceous Lamja Formation from Yola Sub-basin, Northern Benue Trough, NE Nigeria: implication for hydrocarbon-generating potential and paleodepositional setting. Arab J Geosci 8:7371-7386

Sarki Yandoka BM, Abdullah WH, Abubakar MB, Hakimi MH, Adegoke AK (2015b) Geochemical characterisation of Early Cretaceous lacustrine sediments of Bima Formation, Yola Sub-basin, Northern Benue Trough, NE Nigeria: Organic matter input, preservation, paleoenvironment and palaeoclimatic conditions. Mar Pet Geol 61:82-94

Shanmugam G (1985) Significance of coniferous rain frost and related organic matter in generating commercial quantities of oil, Gippsland basin. Australia AAPG Bull 69:1241-1254

Surkov VS, Kazakov AM, Devyatov VP, Smirnov LV (1997) LowerMiddle Triassic rift-ogenic complex of the West Siberian Basin. Otechestvennaya Geologiya 3:31-37

Ten Haven HL, De Leeuw JW, Rullkötter J, Sinninghe Damsté JS (1987) Restricted utility of the pristane/phytane ratio as a palaeoenvironmental indicator. Nature 330:641-643

Tissot B, Welte DH (1984) Geochemical fossils and their significance in petroleum formation, petroleum formation and occurrence. Springer, Berlin, pp 93-130

Tserolas P, Maravelis AG, Tsochandaris N, Pasadakis N, Zelilidis A (2019) Organic geochemistry of the Upper Miocene-Lower Pliocene sedimentary rocks in the Hellenic Fold and Thrust Belt, NW Corfu island, Ionian sea, NW Greece. Mar Pet Geol 106:17-29

U.S. Geological Survey World Energy Assessment Team (2000) U.S. Geological Survey World Petroleum Assessment 2000-Description and results: U.S. Geological Survey Digital Data Series 60, 4 CD-ROMs.

Vyshemirsky VS (1986) Bazhenov Horizon of West Siberia (Bazhenovskiy gorizont Zapadnoy Sibiri): Novosibirsk. Nauka, Russia, p 217

Wang W, Wang T, Li M, Mao F, Liu J, Xiao H, Lai H, Ai X (2021) The origins of biodegraded oils in sandstone reservoirs in the Termit Basin. J Pet Sci Eng 207:109130

Wenger LM, Davis CL, Isaksen GH (2002) Multiple controls on petroleum biodegradation and impact on oil quality. Reserv Eval Eng 5:375-383

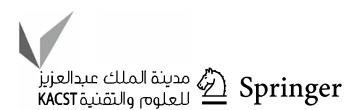

